SEA Volume 8, No. 2 (2019)

\title{
EXPLORING VEGETABLE FARMING IN PERI-URBAN AREAS OF JAKARTA (A CASE STUDY OF TANGERANG REGENCY)
}

\author{
Faisal Fahmi*1, Doddy Aditya Iskandar ${ }^{2}$ \\ ${ }^{1}$ Student of Graduate Program in Urban and Regional Planning; Universitas Gadjah Mada \\ ${ }^{2}$ Lecturer of Graduate Program in Urban and Regional Planning; Universitas Gadjah Mada \\ e-mail: *1faisal.fahmi28@gmail.com
}

\begin{abstract}
The presence of vegetable farmers in peri-urban areas is essential for the supply of food to the urban population. However, they face intense competition from other non-agricultural activities. This research aims to explore the characteristics of vegetable farmers in Tangerang Regency as part of Jakarta Metropolitan Area, the motivation of respondents towards becoming vegetable farmers, and their strategy in adapting to massive urban development. We employed the qualitative approach by combining questionnaires, field observations, and interviews. We found the new entrant farmers that are in their productive ages and came with experience in the formal economy before starting farming. The motivation of respondents became vegetable farmers vary depend on their background and the land ownerships. Farmers in the study area are doing diversification by having off-farm activities and doing intensification by patterning crop to adapt rapid urbanization. To sustain the development of vegetable farming in peri-urban area, it will be crucial for government to create the new strategy of using vacant lands as farmlands to produce vegetables in order to combat food security issues, and also to assist farmers by upgrading their skill through various trainings.
\end{abstract}

Keywords: Peri-urban, Strategy, Vegetable Farming.

\section{INTRODUCTION}

Rapid development in urban areas has led to urbanization. About $45 \%$ of the Asian population lived in urban areas in 2011, and it has been predicted that, by 2050, this will increase to $64 \%$ (United Nations, 2011). For Indonesia context, the urban population reached about $50 \%$ from national population and heavily concentrated in mega cites, especially Jabodetabek (Rustiadi, Pribadi, Pravitasari, \& Indraprahasta, 2015).

As one of the peripheral regions of Jakarta, Tangerang Regency also experiences the phenomenon of urban expansion. In the last ten years, the agricultural areas of Tangerang Regency decreased $8.8 \%$ from the original 40,653 hectares to 37,073 hectares during the 2007-2017 period (Statistics of Tangerang Regency, 2017). Despite the pressure of urban expansion and land conversion, the farming activities in peri-urban areas have persisted in a meaningful context. Sepatan Timur, the area near the Soekarno-Hatta airport, is well known as the vegetable producer for the markets in the Jakarta Metropolitan Area. Farmers in this district can supply up to 40,000 bunches of vegetables (Farma, 2018). 
Farming practices in metropolitan areas has some advantages, such as proximity to the market and lower transportation costs (Midmore \& Jansen, 2003), which can stimulate economic growth (Eweg, 2014), yet face some problems such as economic problems (Firman, 2000), limited access to land and agricultural inputs (Lang, 2010), and policies from government (Eweg, 2014)

In recent years, researchers have been focusing on the strategy that farmers have taken in metropolitan areas of Netherlands, India, and China to adopt urban development (Van Altvorst et al. (2011) in Eweg (2014). In the Indonesian context, Syaifudin (2017) explored the farming strategy of adopting inland aquaculture in Bogor Regency and found that intensification is the dominant strategy and that the most crucial factor is the availability of land. Pribadi and Pauleit (2015) highlighted the importance of studying at the village and farm levels to understand farmers' strategy in adapting to dynamic urban areas better.

There are many studies about the farmers' strategy in metropolitan areas, but few studies focus on vegetable farmers, especially in peri urban areas in Indonesia. Therefore, this study explored the strategy taken by the vegetable farmers in Tangerang Regency. In order to fill the gap, this study asked the following three research questions: 1) What are the characteristics of vegetable farmers in Tangerang Regency? 2) What is the motivation of respondents toward becoming vegetable farmer? and 3) What kind of strategies are applied by farmers in facing the existing issues in vegetable farming?

\section{RESEARCH METHODOLOGY}

\section{Study Area}

Tangerang Regency is located in the eastern part of Banten Province that has an area of $959 \mathrm{~km} 2$ and divided into 29 districts. It is inhabited by 3,477,495 people (Statistics of Tangerang Regency, 2017). As one of the industrial centers in Indonesia, most people in Tangerang Regency work in the manufacturing sector, followed by trade, hotel, restaurant sector, and service sector. Only $4.65 \%$ of people in Tangerang Regency work in the agriculture sector (Statistics of Tangerang Regency, 2017).

Despite its low employment in the agriculture sector, Tangerang Regency produced 10,773.6 tons of horticulture products in 2017 , an increase of $47.10 \%$ when compared to the production in 2015 (Statistics of Tangerang Regency, 2017). Teluk Naga and Sepatan Timur were the two leading producers of horticulture products in Tangerang Regency by $3,131.89$ tons and 1498.5 tons, respectively, in 2017. 


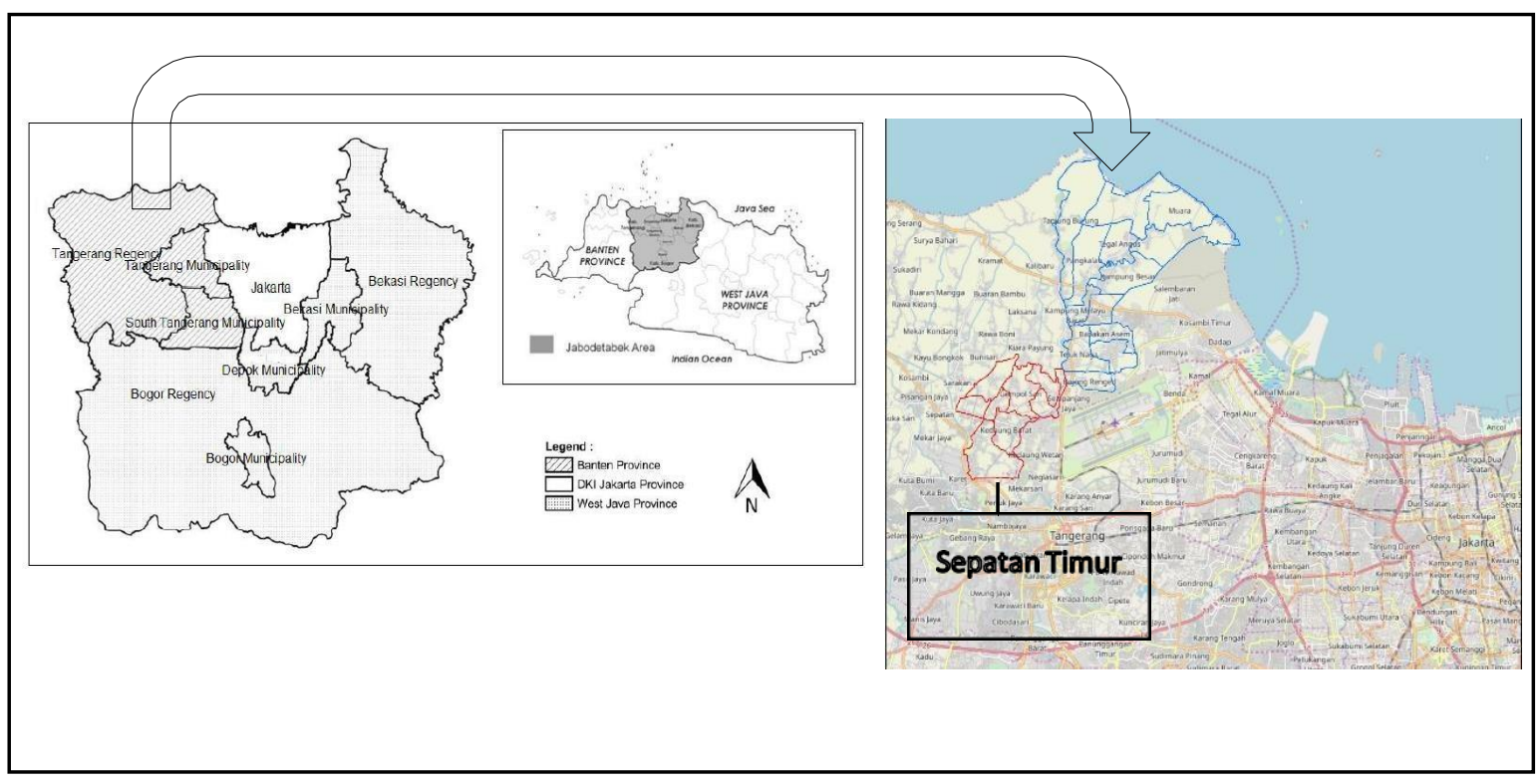

Figure 1. Map of Jakarta Metropolitan Area and study location

Source: Pribadi and Pauleit (2015)

The study area as case study was selected based on a few criteria. The first criterion was the metropolitan area where the urbanization processes happened. Then, the lowland horticulture, as one of agriculture practices that can adapt and benefit from urban development, was selected. Third, the location was taken into consideration, for example, it was situated in an area where urbanization is taking place due to the proximity to the Soekarno-Hatta International Airport. Therefore, Tangerang Regency was selected as the study areas. However, due to limited time, the researcher only conducted the study in one district, namely Sepatan Timur, considering it is one of primary producers of horticulture in Tangerang Regency.

\section{Methods}

This study employed qualitative approach through combination of questionnaires, field observations, and interviews. The questionnaire had several parts to evaluate some aspects, such as human capital, natural capital, physical capital, financial capital, social capital, measures taken by farmers, and government support. In total, there were 52 respondents from Sepatan Timur. The selection of respondents was based on purposeful sampling method. This technique widely used in qualitative approach for identifying and selecting information-rich cases for the most effective use of limited resources (Patton, 2002).The Agricultural Advisory Agency of Sepatan referred the farmers who suitable as respondents.

Interviews conducted in this study aim to obtain the opinions of farmers about the condition of natural resources while practicing vegetable farming, the personal history of becoming a vegetable farmer, and their opinions about government support. There were three interviewees. Farmers were grouped into three categories, namely farmer association as interviewee 1, individual farmer who hire employees as interviewee 2, and an individual farmer as interviewee 3. Farmer association in this study was represented by the farmer association of "Rawa Banteng". He was chosen based on the reference from the Agricultural 
Advisory Agency at Sepatan. The individual farmer who hires employees and the individual farmer were also selected based on the reference from Agricultural Advisory Agency.

The quantitative data, such as income, land area, and income from the questionnaire were analyzed by simple distribution and percentage. Qualitative data obtained from questionnaires were used to explore the people's motivation to start vegetable farming. This data then analyzed by employing cross-tabulation analysis to see the variable that correlates with the motivation of people to start vegetable farming. The Chi-square test is the primary statistic used in this study for testing the statistical significance of the cross-tabulation table. Chisquare tests determine whether or not the two variables correlates each other. Qualitative data obtained through interviews were used to explain the strategies taken by farmers and the challenges and opportunities related to the issue. Data collected from a qualitative approach were processed through three stages of qualitative data analysis, namely data reduction, presentation of data, and conclusion.

\section{RESULTS AND DISCUSSIONS}

Farmers' characteristic and motivation in farming

Table1.Respondents Characteristic

\begin{tabular}{|c|c|c|}
\hline Variable & Frequency & Percentage \\
\hline \multicolumn{3}{|l|}{ Age } \\
\hline $20-29$ & 6 & $11.76 \%$ \\
\hline $30-39$ & 14 & $27.45 \%$ \\
\hline $40-49$ & 15 & $29.41 \%$ \\
\hline $50-59$ & 8 & $15.69 \%$ \\
\hline $60-70$ & 8 & $15.69 \%$ \\
\hline \multicolumn{3}{|l|}{ Education } \\
\hline Elementary School & 32 & $62.75 \%$ \\
\hline Junior High School & 11 & $21.57 \%$ \\
\hline Senior High School & 8 & $15.69 \%$ \\
\hline \multicolumn{3}{|l|}{ Household Number } \\
\hline $0-2$ & 11 & $21.57 \%$ \\
\hline $3-5$ & 31 & $60.78 \%$ \\
\hline $6-8$ & 8 & $15.69 \%$ \\
\hline$>8$ & 1 & $1.96 \%$ \\
\hline \multicolumn{3}{|l|}{ Land Ownership } \\
\hline Own & 22 & $43.14 \%$ \\
\hline Own + Rent & 3 & $5.88 \%$ \\
\hline Rent & 26 & $50.98 \%$ \\
\hline \multicolumn{3}{|l|}{ Land Area } \\
\hline$<0.1 \mathrm{Ha}$ & 8 & $15.69 \%$ \\
\hline $0.1-0.25 \mathrm{Ha}$ & 27 & $52.94 \%$ \\
\hline $0.25-0.5 \mathrm{Ha}$ & 9 & $17.65 \%$ \\
\hline $0.5-1 \mathrm{Ha}$ & 5 & $9.80 \%$ \\
\hline$>1 \mathrm{Ha}$ & 2 & $3.92 \%$ \\
\hline \multicolumn{3}{|l|}{ Farming Experience } \\
\hline $1-8$ & 27 & $52.94 \%$ \\
\hline $9-16$ & 10 & $19.61 \%$ \\
\hline $17-24$ & 9 & $17.65 \%$ \\
\hline $25-32$ & 3 & $5.88 \%$ \\
\hline $49-56$ & 2 & $3.92 \%$ \\
\hline
\end{tabular}

Source: Author analysis (2019) 
Table 1 shows the respondents' characteristics in Sepatan Timur. Farmers in this area are in the productive age (15-64 years old) according to Law Number 13, 2003. More than half of vegetable farmers in this area are in the age range between 30-50 years old. However, only a few of youngers under 30 years old involved in vegetable farming. The respondents also only had lower education attainment. About 60 percent of farmers only graduated from elementary school. This finding is similar to Siregar (2006) who found urban vegetable farmers in Jakarta had low educational levels. In addition, about 60 percent of respondents have 3-5 household numbers.

The other important characteristics are the land ownership and land area. This study depicts that famers that owning land and renting from other people have the relatively same proportion. Farmers who have their own land are $49 \%$ while farmers who rented from others counted for $51 \%$. Most of respondents in this area only have land area which less than 0.25 hectare. More than $50 \%$ of farmers have an agriculture land with 0.1 up to 0.25 hectare. Farmers who managed more than one hectare of land are less than five percent. Vegetable farming is a form of intensive agriculture that needs only small area of land to produce large volume of output (FAO, 2007).

From the table, we can see that more than $50 \%$ respondents have vegetable farming experience in less than eight years. They are new entrant farmers who did various former jobs before decided to be farmer. Figure 1 illustrates the former job of respondents in research location before decided to become vegetable farmers.

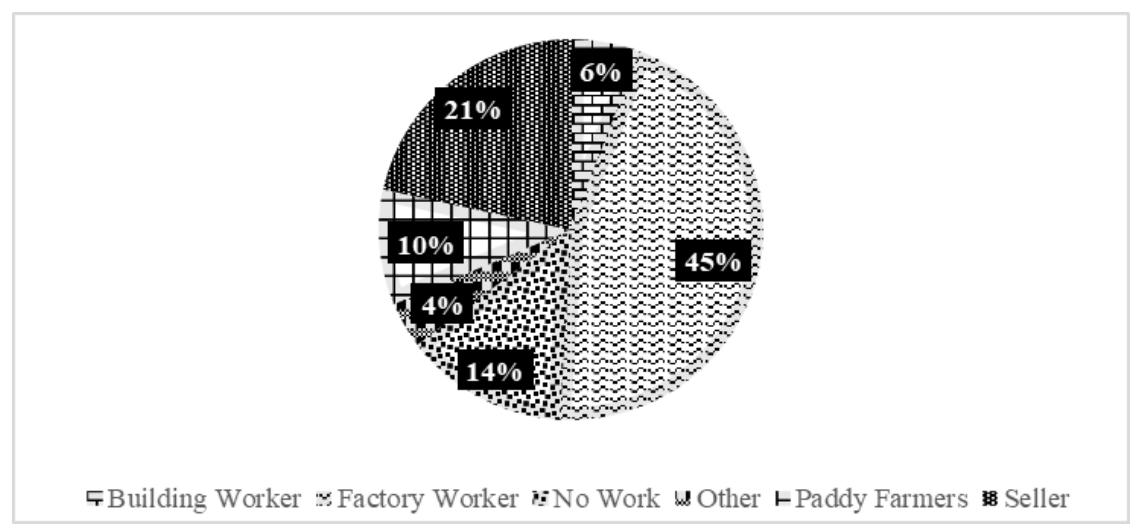

Figure 1. Former job of respondents before started vegetable farming

The most noticeable former job of respondents is factory workers. About half of respondents $(45 \%)$ used to involve in formal job (factory workers) before decided to be vegetable farmers. The considerable number of people who held jobs as factory workers previously attests to the status of Tangerang Regency as one of the industrial centers in Indonesia. The number of large and medium industrial enterprises accounted for 695 in 2013 when 174,531 workers were employed (Statistics of Tangerang Regency, 2014).

Then, we explore the reason of respondents chose the vegetable farmer as an occupation. Figure 2 depicts the various reason of respondent in deciding to be vegetable farmers. 


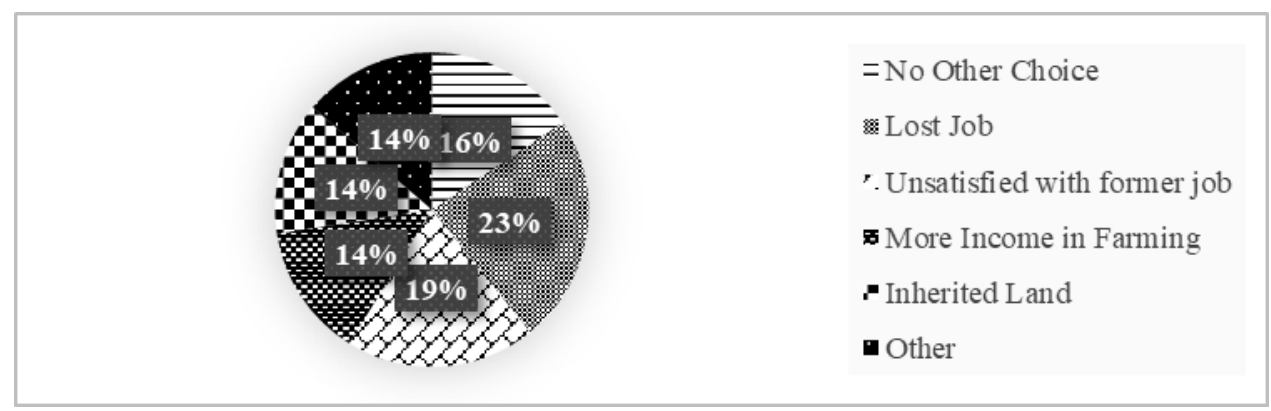

Figure 2. The reason of respondent for becoming vegetable farmers

The main reason respondent started vegetable farming is unemployment due to job loss. The economic crisis of 1998 forced the manufacturing firms in the Jakarta Metropolitan Areas to close their businesses and lay off workers (Firman, 2002). In Tangerang Regency, the type of industries that closed due to the crisis are shoes and garments which are labor-intensive industries. For an example in 2015, two companies (PT Jabar Garmindo dan PT Cingluh) in the Cikupa District, Tangerang Regency, laid off 6,500 workers due to difficulties paying their salaries (Tempo, 2015).

Table 3. Chi-Square Tests

\begin{tabular}{llll}
\hline & Value & Df & $\begin{array}{l}\text { Asymptotic Significance } \\
\text { (2-sided) }\end{array}$ \\
\hline Pearson Chi-Square & & 2 & .029 \\
Likelihood Ratio & $7.114^{\mathrm{a}}$ & 2 & .025 \\
Linear-by-Linear Association & 7.383 & 1 & .201 \\
N of Valid Cases & 1.633 & & \\
\hline
\end{tabular}

Source: Primary data analysis (2019)

The cross-tabulation in Table 2 tries to explore the correlation between former jobs and the reason for respondents to begin vegetable farming. We reclassified the former jobs into two groups: formal and informal jobs while the reasons of respondents are classified into three groups: no other choice, more income in farming, and other. In this study, the formal job includes only factory workers while informal jobs include paddy field farmers, building workers, and small traders.

Table 2. Cross tabulation between former job and reason started vegetable farming

\begin{tabular}{llrrrr} 
& & \multicolumn{3}{c}{ Reason } & \multicolumn{1}{c}{} \\
\cline { 3 - 6 } & & $\begin{array}{c}\text { No Other } \\
\text { Choice }\end{array}$ & $\begin{array}{c}\text { More Income } \\
\text { in Farming }\end{array}$ & Other & \multicolumn{2}{c}{ Total } \\
\hline Former Job & Formal Job & 9 & 4 & 10 & 23 \\
& Informal Job & 11 & 13 & 4 & 28 \\
Total & & 20 & 17 & 14 & 51 \\
\hline
\end{tabular}

Source: Primary data analysis (2019) 
The chi-square test in Table 3 shows that asymptotic significance value is 0.029 . This value is less than 0.05 then it means that there is correlation between former job and reason of respondents began their vegetable farming. Zezza \& Tasciotti (2010) argued that vegetable farming as part of urban agriculture can be source of income for people in developing countries.

The motivation of respondent in choosing the agriculture as a means of livelihood becomes an exciting area for discussion. The pattern of occupation shifted from nonagricultural to agricultural in research location contrast with the trend of occupation shift in the world. The share of agricultural workforce has declined in the last 15 years in most regions. The rate of decline of the agricultural workforce has much faster in Asia; the rate of change has gone up to $15 \%$ (Bongaarts, 2006). Youth are more interested in modern and formal employment and see practicing agriculture more challenging, both physical and mentally (Leavy \& Hossain, 2014).

The motivation of respondents became vegetable farmers vary depend on their background and the land ownerships. Interviewee 1 who had background in agricultural vocational school and inherited agriculture land from his parents revealed that independence is the main motivation.

"I used to work at the factory for three months, because of strict working hours when I worked at the factory I feel couldn't stand, I did not feel at home. From there, I realized that there was a large area of land, how did I manage this. And then I tried to make a plot for vegetables"

Interviewee 2 who had experienced in various informal jobs, had background in building design vocational school stated that economic as the main motivation for starting vegetable farming. He rented large area in Tangerang Regency to run his own business in vegetable farming.

"I did not immediately work as a farmer, I used to work in building work. I also was a porter at the airport for one to two years. The beginning of my interest in cultivating vegetable, namely before plunging into a vegetable farmer, I first sold vegetables, by trading Bangkok papaya. Finally, I got trust from the market, then I considered that the competition is running faster, inevitably I must produce vegetable and fruits by myself and must definitely produce it by myself".

Motivation that found in Interviewee 1 is in line with the study by Gasson and Errington (1993) in Sutherland and Fouillieux (2017) that found the independence of running own business is the main factor for the adoption of farming. Wilbur (2014) argued that the agriculture can also acts as a form to escape from employment hierarchies. On the other hand, motivation that found in Interviewee 2 related to the study by Madureira et al. (2015) that identified financial crisis as the emergence of small business in farming enterprises in Portugal.

\section{Farmers' strategies in the study area}

The perception of job satisfaction for being vegetable farmers in this area shows that most respondents are not satisfied by income in vegetable farming. Most of respondents $(65 \%)$ answer "Not Satisfied" when asked about job satisfaction. They perceived that income from farming is not sufficient to fulfill their daily needs. 
Therefore, they are doing many ways to tackle this problem. Figure 3 shows the various strategy of farmers to fulfill their needs. More than a half of respondents (57\%) answered "Add off-farm activity" as a strategy for adding their income. This number is quite in line with the number of respondents who have side job (51\%). They spent about three to four hours per day to do side job. Diversification in any form of off-farm activities can be a solution to the income problem faced by farmers (Meert, Van Huylenbroeck, Vernimen, Bourgeois, and Van Hecke, 2005).

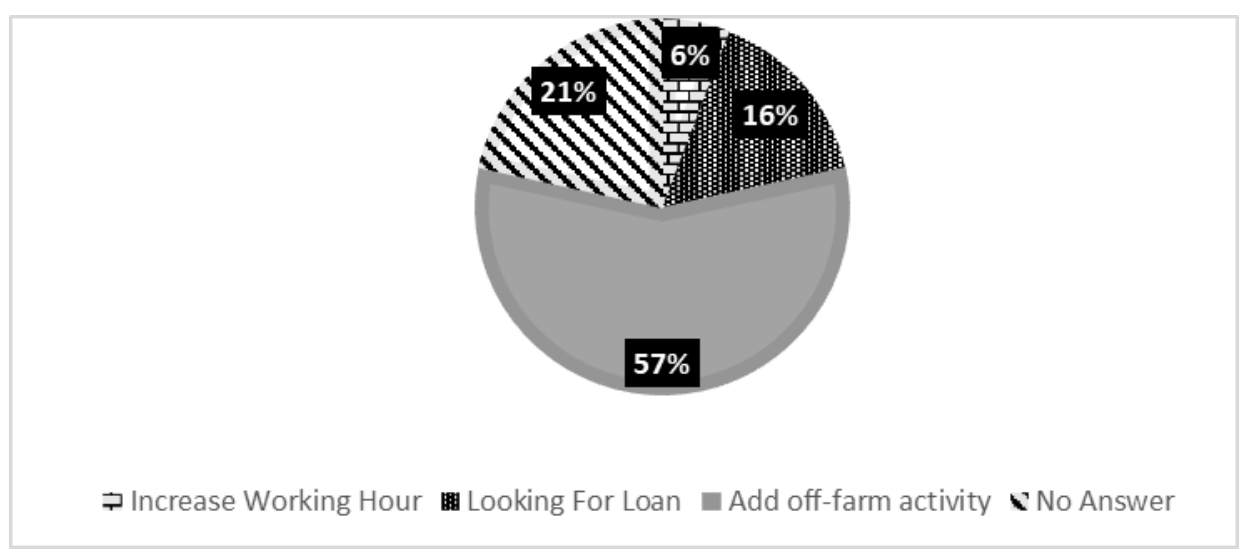

Figure 3. Farmers' strategy to fulfill daily needs

Strategies taken by farmers also involve strategies of production, marketing, and obstacles that farmers use to deal with managing their farmlands. Farmers in Sepatan Timur focus on three types of horticulture products, namely spinach, swamp cabbage (kangkong), and choy sum. Those three products are perishable, so that farmers must quickly sell their products to the market. The location of Tangerang Regency allows farmers to easily fulfill the demand of urban residents. Santika (1997) in Siregar (2006) argued that vegetable farming in peri-urban areas has an advantage in terms of the guarantee of continuous demand from urban areas. Interviewee 2 declared that the proximity to the market is one of the benefits of doing farming in the periphery of city.

"...the advantage of farming close to the city like here in Tangerang, the buffer zone of the capital city Jakarta that has the highest number of vegetable consumer. It means the marketing of our products become easier"

Three leading vegetable products in Tangerang Regency are swamp cabbage, spinach, and choy sum. In total, those three vegetables contribute to around $70 \%$ of the total production of vegetables in Tangerang Regency. This figure is quite in line with the trend of vegetable consumption in Indonesia. Indonesian consumers mainly consume three types of vegetables, namely spinach, swamp cabbage, and yard long bean (World Food Program Indonesia, 2017).

As stated before, farmers in this area manage the agriculture land which less than 3,000meter square. By considering the market dynamics and weather condition, farmers making pattern of planting that can ensure they can harvest vegetables every day even they only manage a narrow land.

“...even though the land is narrow, at most 3000,4000 to 5000 square meters, we pattern the plants. For the rainy season from January to May if we can plant leafy vegetables 
because the price is good. Well, after the fifth month, we have variations in monthly or seasonal plants such as onions and chilies or eggplant"

From the result of study, it can be concluded that farmers in Tangerang Regency implemented intensification as their farming strategy. This study shows the similar result with Syaifudin (2017) who found the intensification as the dominant strategy in inland aquaculture in Bogor Regency. Eweg (2014) argued that sustainable intensification means farmers cooperate with their food producer colleagues in providing intensive production methods. In Tangerang Regency, farmers cooperate with the middlemen to distribute their products to the market.

Farmers cooperate with intermediaries due to the lack of transportation means. The intermediaries are the main actors for distributing products from the field to the market. By collaborating with distributors, farmers can minimize their transportation costs. However, they end up not having information about the prices at which their produce is sold in the market. The distributors will pay the farmers after selling the products in the market. The price is determined by market dynamics.

“...my products are sold entirely to the intermediaries with bulk systems. The price, whether it is or expensive fully controlled by the intermediaries. If there are no intermediaries like this, we are even confused about market place to sell our products"

Farmers from Sepatan Timur supply vegetables to Jakarta, Tangerang Regency, and Tangerang City. Pasar Induk Kramat Jati is the marketplace for selling the products in Jakarta. Pasar Anyar and Pasar Baru are the marketplaces for catering to the demand in the Tangerang area. On average, the farmer can send about 1500 bunches of vegetables in each delivery.

From the interview result, the main obstacle faced by vegetable farmers is the uncertainty about price of the product and the increase in seeds price. Both individual farmers and farmer associations have revealed that the uncertainty about the price of products is the main problem faced by vegetable farmers.

"Vegetables are not a primary necessity like rice, so the price is not stable" (Interviewee 3, 2019)

"This vegetable prices change very quickly, it changes even in count of hours and actually depends on the market, especially for leaf vegetables" (Interviewee 1, 2019)

Farmers perceived that lack of agricultural equipment becomes their problem. Farmers in study area are small-holder farmers who do not have the significant capital required to buy equipment. They need support from the others especially from the government. However, only $44 \%$ of respondents answer that have been supported by government. They collaborate with other farmers in the farmer group to overcome the problem in agricultural equipment. Farmer group can lend some of agricultural equipment that farmers needed.

Farming in peri-urban areas brings more challenges, especially land competition from other sectors. The research location that is incredibly near Soekarno- Hatta International Airport has brought about intense rivalry between the farmers in both areas in terms of the development of warehouse, residential areas, shopping centers, and the expansion of the airport itself. 
Sepatan Timur has been set as agricultural areas in the Spatial Planning of Tangerang Regency 2011-2031. This law helps preserve the agriculture areas in Sepatan Timur from conversion to non-agricultural land. Under this law, Sepatan Timur has also been set as agropolitan to guarantee food security in Tangerang Regency.

The local government of Tangerang Regency has implemented the policy of spatial planning that mandates that rural areas must develop agriculture towns for supplying food to urban residents. The law of spatial planning that mandates development of agropolitan areas was issued as a response of the second crisis in 2007 (Pribadi \& Pauleit, 2015b).

\section{CONCLUSION AND RECOMENDATIONS}

Vegetable farmers in Tangerang Regency are in productive age and new entrant farmer due to lost job as the result of financial crisis and closure of industries. They also have small area of agricultural land. The motivation of respondents to become vegetable farmers related to the independence in running own business and economic endures because of economic crisis and the absence of formal employment.

Farmers in study area implemented diversification by having side-job outside farming activities in adapting urban development pressure and implemented intensification as a strategy in managing small area of agriculture. Vegetable farming provides a better income even from small plots in a brief period; however, farmers perceived that the income is not sufficient, so they still look for added income from side jobs.

It is a crucial role of the government to hold training for upgrading farmers' skills and encourage farmers to use ICT for getting the updated information about farming and market. It will be crucial to consider the utilization of vacant land in peri- urban areas to produce various types of vegetables and fruits and to adjust the lower land; it might be important to encourage collaboration activities with state-owned enterprises and universities toward research and development for providing better quality of seeds.

\section{REFERENCES}

Bongaarts, J. (2006). 2017 The State of Food and Agrivulture Leveraging Food Systems for Inclusive Rural Transformation. Population and Development Review (Vol. 19). https://doi.org/10.2307/2938399

Eweg, R. (2014). Towards sustainable Metropolitan Agriculture. In Why we need small cows, Ways to Design for Urban Agriculture (pp. 295-309). VHL University of Applied Sciences.

FAO. (2007). Profitability and sustainability of urban and peri-urban agriculture.

Farma, S. (2018). Budidaya Organik; Harapan Petani Hortikultura di Banten | MONITOR. Retrieved January 28, 2019, from https://monitor.co.id/ekonomi/pertanian/budidaya-organik-harapan-petanihortikultura-di-banten/

Firman, T. (2000). Rural to urban land conversion in Indonesia during boom and bust periods. Land Use Policy, 17, 13-20.

Firman, T. (2002). Urban development in Indonesia, $1990-2001$ : from the boom to the early reform era through the crisis. Habitat International, 26, 229-249.

Lang, T. I. M. (2010). Crisis? What Crisis? The Normality of the Current Food Crisis. Journal of Agrarian Change, 10(1), 87-97.

Leavy, J., \& Hossain, N. (2014). Who Wants to Farm? Youth Aspirations, Opportunities and 
SEA Volume 8, No. 2 (2019)

Rising Food Prices. IDS Working Papers (Vol. 2014). https://doi.org/10.1111/j.20400209.2014.00439.x

Madureira, L., Koehnen, T., Vinohradnik, K., Kania, J., Creaney, R., Duckett, D., \& Ann, L. (2015). Advisory services for small-scale farmers : how effective is its response to farmers needs and demands? Retrieved from www.proakis.eu/publicationsandevents/pubs

Meert, H., Van Huylenbroeck, G., Vernimmen, T., Bourgeois, M., \& van Hecke, E. (2005). Farm household survival strategies and diversification on marginal farms. Journal of Rural Studies, 21(1), 81-97. https://doi.org/10.1016/j.jrurstud.2004.08.007

Midmore, D. J., \& Jansen, H. G. P. (2003). Supplying vegetables to Asian cities: Is there a case for peri-urban production? Food Policy, 28(1), 13-27. https://doi.org/10.1016/S0306-9192(02)00067-2

Patton, M. Q. (2002). Qualitative research and evaluation methods (3rd ed.). California America: Sage Publications, Inc.

Pribadi, D. O., \& Pauleit, S. (2015a). Land Use Policy The dynamics of peri-urban agriculture during rapid urbanization of Jabodetabek Metropolitan Area. Land Use Policy, 48, 13-24. https://doi.org/10.1016/j.landusepol.2015.05.009

Pribadi, D. O., \& Pauleit, S. (2015b). The dynamics of peri-urban agriculture during rapid urbanization of Jabodetabek Metropolitan Area. Land Use Policy, 48, 1324. https://doi.org/10.1016/j.landusepol.2015.05.009

Rustiadi, E., Pribadi, D. O., Pravitasari, A. E., \& Indraprahasta, G. S. (2015). Jabodetabek Megacity : From City Development Toward Urban Complex Management System. In Urban Development Challenges, Risks and Resilience in Asian Mega Cities (pp. 421445). https://doi.org/10.1007/978-4-431-55043-3_22

Siregar, M. (2006). Peri-Urban Vegetable Farming in Jakarta. In Seminars Urban/Peri-urban Agriculture in the Asian and Pacific Region (pp. 69-84). Retrieved from

http://www.agnet.org/htmlarea_file/activities/20110719103448/paper-651571206.pdf

Statistics of Tangerang Regency. (2014). Tangerang Regency in Figures 2014. Tangerang Regency

Statistics of Tangerang Regency. (2017). Tangerang Regency in Figures 2017. Tangerang Regency.

Sutherland, L. A., \& Fouillieux, E. (2017). EIP-AGRI Focus Group - New entrants into farming: lessons to foster innovation and entrepreneurship. European Union Politics. Retrieved from https://ec.europa.eu/eip/agriculture/sites/agri-eip/files/eipagri_fg_new_entrants_final_report_2016_en.pdf

Syaifudin, A. (2017). Exploring Farming Strategies in a Metropolitan Area: Case study of Inland Aquaculture in Bogor Regency. Wageningen University.

Tempo. (2015). PHK di Tangerang Capai 6.500 Buruh - Bisnis Tempo.co. Retrieved from https://bisnis.tempo.co/read/707553/phk-di-tangerang-capai-6-500buruh/full\&view=ok

United Nations. (2011). World Population Prospects The 2010 Revision (Vol. I).

Wilbur, A. (2014). Cultivating back-to-the-landers: Networks of knowledge in rural Northern Italy. Sociologia Ruralis, 54(2), 167-185. https://doi.org/10.1111/soru.12024

World Food Programme Indonesia. (2017). Buletin Pemantauan Ketahanan Pangan Indonesia Fokus Khusus: Tren konsumsi dan produksi buah dan sayur (Vol. 8).

Zezza, A., \& Tasciotti, L. (2010). Urban agriculture, poverty, and food security: Empirical evidence from a sample of developing countries. Food Policy, 35(4), 265-273. https://doi.org/10.1016/j.foodpol.2010.04.007 